\title{
IDH2 NP_002159.2:p.R172G
}

National Cancer Institute

\section{Source}

National Cancer Institute. IDH2 NP 002159.2:p.R172G. NCI Thesaurus. Code C131109.

A change in the amino acid residue at position 172 in the isocitrate dehydrogenase

[NADP], mitochondrial protein where arginine has been replaced by glycine. 